\title{
Luckács e a literatura como mediação ontológica do ser social
}

\author{
Denilson Albano Portácio \\ Secretaria de Educação do Estado do Ceará ${ }^{1}$ \\ Aline Laureano Machado \\ Universidade Estadual do Ceará ${ }^{2}$ \\ Ana Carmen Silva \\ Universidade Estadual do Ceará ${ }^{3}$
}

Resumo: A proposta do artigo consiste em apresentar o resultado de uma pesquisa bibliográfica realizada com o objetivo de investigar o uso da literatura como mediação para uma formação humana partindo da contribuição do método lukacsiano que, baseado no materialismo histórico dialético, compreende a arte como um processo histórico resultante do mundo dos homens. Trata-se de um estudo de cunho bibliográfico e documental ancorando-se inicialmente nas contribuições de Lukács, Marx, Saviani e Mészáros. Compreende-se que o ensino da arte, especificamente em se tratando da literatura, deve valorizar sua função social, superando os conceitos de educação artística e de educação a partir da arte, mas não se limitando à arte-educação esvaziada. A relevância do estudo se dá-se pelo fato de que além de abrir portas para um debate sobre o ensino da arte literária, possibilita também a base para estudos posteriores no propósito de investigar sobre essas aproximações iniciais.

Palavras-chave: Literatura; Formação humana; Estética de Lukács.

\section{Luckács and literature as ontological mediation of the social being}

\begin{abstract}
The proposal of the article is to present the result of a bibliographic research with the objective of investigating the use of literature as mediation for human formation based on the contribution of the Lukachian method that, based on dialectical historical materialism, understands art as a historical process resulting from the world of men. This is a bibliographic and documentary study, initially anchoring itself in the contributions of Lukács, Marx, Saviani and Mészáros. It was understood that the teaching of art, specifically when it comes to literature, should value its social function, overcoming the concepts of artistic education and education from art, but not limited to empty art-education. The relevance of the study is given by the fact that in addition to opening doors to a debate on the teaching of literary art, also provides the basis for further studies on the purpose of investigating these initial approaches.
\end{abstract}

Keywords: Literature; Human formation; Aesthetics of Lukács.

\footnotetext{
1 Técnico em Educação da Secretaria de Educação do Estado do Ceará (SEDUC). ORCiD: https://orcid.org/0000-0001-7481-2077.E-mail: denilsonap@seduc.ce.gov.br.

2 Mestranda em Educação do Programa de Pós-Graduação em Educação da Universidade Estadual do Ceará (PPGE-UECE). ORCiD: https://orcid.org/000-0002-6670-9413. E-mail: alinemachado200@hotmail.com.

${ }^{3}$ Mestranda em Educação do Programa de Pós-Graduação em Educação da Universidade Estadual do Ceará (PPGE-UECE). ORCiD: https://orcid.org/000-0002-6040-7385. E-mail: anacarmensilva@hotmail.com.
}

Cadernos GPOSSHE On-line, Fortaleza, v. 5, n. 1, 2021

https://revistas.uece.br/index.php/CadernosdoGPOSSHE

DOI: $10.33241 /$ cadernosdogposshe.v5i1

ISSN: $2595-7880$ 


\section{INTRODUÇÃO}

Este trabalho pretende pensar a fruição literária no contexto educativo defendendo que o ensino da arte deve ser entendido como elemento de aprimoramento dos sentidos estéticos indispensáveis para a formação do ser humano como ser social e para o desenvolvimento de uma consciência crítica perante a realidade da sociedade capitalista contemporânea.

Esta temática tem sua relevância no fato de que o acesso à arte e às condições sensitivas de fruição dela, através de seu ensino, na escola pública de Educação Infantil, configura-se como instrumento propiciador das condições para um ser humano enriquecido de objetivações. Isso posto, é preciso compreender essa problemática e, com base na teoria lukacsiana, identificar elementos para uma práxis revolucionária.

Nos pontos acima descritos, o referido trabalho estrutura a pesquisa bibliográfica feita acerca dos complexos da arte, da estética e do educar literário, tencionando analisar o método realista lukacsiano como via de construção e possibilidade da fruição da arte. Superando, portanto, toda e qualquer ideia de imanência do texto, ao contrário, a elaboração está intimamente ligada a uma totalidade social. Este trabalho tem seu aporte introdutório resultante das leituras iniciais em György Lukács e Karl Marx. Possibilitou-nos galgar no campo da arte a compreensão dos referidos autores acerca deste complexo.

$\mathrm{O}$ artigo se divide em quatro partes. Inicialmente, nomeada de, $\mathrm{O}$ trabalho como protoforma de todas as práxis sociais, tratando-se da função exercida pelo trabalho sobre a atividade humana consciente, no segundo ponto Arte e humanidade na perspectiva de Lukács; discorre-se sobre o conceito lukacsiano da arte no mundo dos homens como criação própria e tardia, No terceiro tópico, A literatura como mediação do ser social, a análise é direcionada à educação dos sentidos humanos como ponto determinante para a fruição da arte literária. Por fim, a quarta parte aborda Literatura e realismo conforme Luckács, desenvolvimento e historicização da arte literária à luz de Luckás.

\section{O TRABALHO COMO PROTOFORMA DE TODAS AS PRÁXIS SOCIAIS}


Para que os homens possam existir e, construírem a história do gênero humano, estes precisam antes de tudo permanecerem vivos. É a partir desse pressuposto que Marx e Engels afirmam que os homens precisam suprir as suas necessidades elementares para assegurarem a sua existência e reprodução material a fim de que possam fazer história. "O primeiro ato histórico é, pois, a produção da própria vida material”. Marx; Engels (2008, p. 33). A produção da existência material dos homens somente foi possível mediada a práxis fundante que é o trabalho. Para Lukács (2013, p. 43) a essência do trabalho consiste "no fato de que em primeiro lugar, ele nasce em meio a luta pela existência e, em segundo lugar, todos os seus estágios são produtos de sua auto atividade”.

O trabalho possibilitou aos homens características mais propriamente humanas, isto é, com traços de sociabilidade pelo fato de o ser social através do trabalho as afastarem das barreiras naturais, devido ao um salto o qual Lukács (2013) denomina de salto ontológico, que possibilitou aos homens de sobressair de um nível ${ }^{4}$ de ser a outro. Todavia, a existência humana está eternamente relacionada com a natureza. Sem a natureza, os homens, a realidade social seria inviável e impossível de existir. Tal como Marx (2010) nos adverte dessa dependência ontológica dos homens em relação a natureza

\begin{abstract}
"A natureza é o corpo inorgânico do homem, a saber a natureza enquanto ela mesma não é o corpo humano. O homem vive da natureza significa: a natureza é o seu corpo, com o qual ele tem de ficar num processo contínuo para não morrer. Que a vida física e mental do homem está interconectada com a natureza não tem outro sentido senão que a natureza está interconectada consigo mesma, pois o homem é uma parte da natureza" (MARX, 2010, p. 84).
\end{abstract}

Diante dessa afirmativa de Marx (2010), compreende-se que os homens são parte da natureza, ou seja, por mais que a sua atividade criativa que é o trabalho não os coloca em uma posição de independência da natureza, mas interconecto com a natureza, sem possibilidades de supera- lá. O trabalho como criador de valores de uso conforme denomina

\footnotetext{
${ }^{4}$ Lukács (2013) nos apresenta as três esferas que sustentam a existência do ser social que são as seguintes: a esfera inorgânica que é composta pelos elementos que se transformam em outro ser (montanha que se transforma em vale, pedra que se modifica em areia. E a esfera orgânica na qual estão inseridos os seres biológicos ou o mundo natural que somente repõem o mesmo e, por último a esfera do ser social que surgiu da natureza orgânica que conforme afirma Lukács (2013, p. 201) "ele forçosamente preserva as características ontológicas de sua origem". A esfera do ser social se sobressai das demais esferas pela capacidade do ser social produzir sempre o novo, mas sem romper o vínculo ontológico com as esferas orgânicas e inorgânicas.
}

Cadernos GPOSSHE On-line, Fortaleza, v. 5, n. 1, 2021

https://revistas.uece.br/index.php/CadernosdoGPOSSHE

DOI: $10.33241 /$ cadernosdogposshe.v5i1

ISSN: $2595-7880$ 
Marx (2011, p. 112) de trabalho útil é "uma eterna condição de existência do homem, independente de todas as formas sociais. Eterna necessidade natural de mediação do metabolismo entre homem e natureza e, portanto, da vida humana".

Marx (2011) esclarece que o trabalho se constitui em uma atividade exclusivamente pertencente aos homens. Os animais não trabalham pois não existe neles a capacidade de produzir em demasia algo novo, pois estes estão presos as barreiras biológicas. $\mathrm{Na}$ sua clássica citação Marx (2011) diferencia a atividade dos animais em relação a atividade do trabalho entre os homens.

\begin{abstract}
"Uma abelha executa operações semelhantes a do tecelão, e uma abelha envergonha muitos arquitetos com a estrutura de sua colmeia. Porém, o que desde o início distingui o pior arquiteto da melhor abelha é o fato de que o primeiro tem a colmeia em sua mente antes de construí-la com a cera. No final do processo de trabalho, chega-se a um resultado que já estava presente na representação do trabalhador no início do processo, portanto, um resultado que já existia idealmente (MARX, 2011, p. 327).
\end{abstract}

Desse modo, a capacidade dos homens de prever os resultados de suas ações mentalmente antes mesmo de efetivarem as suas ações, Luckács (2013) denomina de préviaideação que é exclusivamente encontrada nos homens e, com isso, possibilitou aos homens a se diferenciarem dos demais animais. Ao ser objetivada, isto é, quando a atividade do trabalho é efetivada, exteriorizada, os homens adquirem conhecimentos e habilidades que não possuíam anteriormente e, com isso, enriquecem a sua subjetividade.

Portanto, o trabalho se constitui em uma atividade teologicamente orientada a um fim e, para a realização do trabalho os homens precisam construir os meios e instrumentos de trabalho, pois sem os instrumentos a transformação da natureza não seria possível. Marx (2011, p. 328) demostra que o trabalho é constituído de processos que se divide em três momentos os quais são estes: "primeiro lugar, a uma atividade orientada a um fim, ou trabalho propriamente dito; em segundo lugar, seu objeto e, em terceiro seus meios". Os meios de trabalho são partes da natureza transformada em um objeto que servirá na mediação dos homens a produzirem outros objetos. Diante disso Vásquez (2007) explicita que 
de relação entre o homem e a natureza e, nesse sentido, é um índice revelador do desenvolvimento da força de trabalho e de seu domínio sobre a natureza" (VÁSQUEZ, 2007, p. 228).

O trabalho é, portanto, o modelo de toda práxis social. A categoria da práxis de acordo com Netto e Braz (2006, p. 43) envolve "o trabalho, que na verdade é o seu modelo - mas inclui muito mais do que ele: inclui todas as objetivações humanas", ou seja, do trabalho se originou outras práxis secundárias que têm por intuito transformar a consciência do ser social. Netto e Braz (2006) asseveram o que diferenciam a práxis originária que é o trabalho o qual se fundamenta na relação homem e natureza, enquanto as práxis secundárias se organizam entre a relação sujeito a sujeito. Tais práxis secundárias são: ciência, religião, direito, linguagem, educação e a práxis artística.

A práxis artística se consolidou tardiamente, esclarece Frederico (2013, p. 44) que a arte "reúne o projeto subjetivo do homem ao mundo material, a arte é entendida não só como um modo de conhecer o mundo exterior [...] mas também como um fazer, uma práxis que permite ao homem afirmar-se ontologicamente". A práxis artística tem um caráter criativo assim como o próprio trabalho. Contudo a arte se diferencia do trabalho pelo fato de que os homens através da arte a utilizam como "um meio de projeção dos anseios subjetivos que transcendem a realidade imediata" (Frederico, 2013, p. 44).

Em síntese, o trabalho como a práxis central de toda sociabilidade humana foi responsável pela consolidação de um novo ser capaz de dar respostas aos desafios impostos pela sua própria autoatividade. A práxis artística cumpre uma função histórica de educar e elevar os sentidos humanos tornando-os cada vez mais social.

\section{ARTE E HUMANIDADE NA PERSPECTIVA DE LUKÁCS}

Antes de tudo, o filósofo inaugura o pensamento e o desenvolvimento da linguagem antecedentes ao desenvolvimento da arte. As experiências humanas surgem no solo cotidiano e desempenham uma função na vida dos homens possibilitadas pela arte.

[...] Lo estético está ya pués presente em sí; para conquistar su auténtico Ser- ParaSí tiene que perforar la oclusión transcendente, tiene que poner como fin ultimo 
y único verdadeiro em estos contextos la evocación de la autoconsciência humana. (LUKÁCS, 1966, p. 294).

Lukács trata acerca do em si, elencando a um sujeito social que produziu em contrapartida, um para si, o que possibilita na observação do filósofo um fazer de identidade entre sujeito e objeto. Ou seja, essa relação pressupõe: pensamento e realidade, subjetividade e objetividade, numa unidade de mútua determinação.

Ao abordar e elevar a categoria do cotidiano, Lukács mais uma vez confirma em sua Estética sobre a verdade do surgimento da arte a partir das práticas do ser social cada vez mais imerso no cotidiano. A Arte e a Ciência contrapostas como forma de conhecimento e de formação humana, são, portanto, indispensáveis. A Arte desenvolve a si mesma uma autonomia de um mundo próprio. Nessa posição, aclara-se que a Arte assume em si mesma um mundo autônomo, exprime uma realidade que toma o ser social como um todo, despertando a sua genericidade consciente. Vale ressaltar que para tal, a arte necessita de suas mediações. A ação de tornar universal o ser social por meio do fenômeno artístico que se diferencia da ciência desantropomórfica, conforme Lukács (1982), no qual conformado artisticamente se liberta do particular, da cismundaneidade, necessidade, contudo, sem perder a validação da imediaticidade individual. Ao preservar a individualidade do objeto, eleva de maneira superior e positiva sua autoconsciência.

Para Lukács a arte não possui um cunho prático. Para o filósofo esse complexo desvela uma função social sobre a vida do homem em sua essência. O conhecimento possibilitado pela arte, posto ao gozo estético é resultado de todo um trabalho sem fins práticos. Seu resultado fruitivo é a elevação do homem imerso em sua cotidianidade, o homem que Lukács afere a categoria de homem inteiro. A respeito dessa categoria, ressaltase que mais à frente será abordada em contraposição à categoria de homem inteiramente. Retomando a respeito da arte, compreende-se que esse ato fruitivo provoca ao ser social uma nova visão de mundo e dos problemas da humanidade. Ou seja, o homem em si, mas ao mesmo tempo o homem genérico.

[...] pero hay además outro punto de vista desde el cual se aprecia, que el objeto del reflejo estético no puder ser general: la generalicación estética es a elevación de la individualidade a lo típico y no, como em la científica el descubrimineto de 
la conexión entre ele caso individual y la legalidade general (LUKÁCS, 1966, p. 249).

Buscar o entendimento da arte no mundo dos homens é tentar compreender também sua gênese e sua estrutura. Entendeu-se com base nas leituras dos Manuscritos econômicofilosóficos de Marx e o tomo I da Estética de Lukács a esse respeito que o caminho para a compreensão acerca do complexo da arte, seria o mesmo que desvelaria sua função social.

Por meio da arte, os homens se humanizam, se educam, evocam sentimentos e estes se voltam para a elevação da consciência dos sujeitos. O complexo artístico é resultado do desenvolvimento histórico da objetividade e da subjetividade humana. Relativo à finalidade que a arte opera, Lukács (1966, p. 274) expõe que "A arte opera diretamente sobre o sujeito humano, o reflexo da realidade objetiva, o reflexo dos homens sociais em suas relações recíprocas, no seu intercâmbio o social com a natureza, é um elemento indispensável”.

Buscou-se salientar pontos basilares existentes entre o ser social e a arte enquanto elemento qualitativo e de formação humana. O reflexo estético da arte não provocará a carência de confundir-se com a objetividade existente da realidade e imanente do complexo da Ciência. Embora a arte seja resultado de toda uma atividade humana, portanto, do trabalho, conforme aludido um pouco mais acima, não está comprometida com o utilitarismo prático da vida cotidiana. Mas, elevará o sujeito do seu cotidiano pragmático e imediato a fim de possibilitá-lo enriquecer-se.

La génesis de lo estético es un análogo desprenderse de la autoconsciencia repecto de la prática cotidiana, como la génesis de la "consciência de" en la independentización del reflejo cientifico de la realidade. Ahora estará ya claro que este desprendimento no es ninguna supresión del reflejo antropomorfizador, sino sólo la constituición de una peculiar especie del mismo, independiente y qualitativamente nueva. Cierto que la tendencia antropomorfizadora es tan general que sólo el reflejo cientifico de la realidade consegue uma ruptura radical com ella: ésta es, objetiva y subjetivamente (e incluso para la posterior conceptuación) uma de las mayores dificuldades que se oponen a la segregación de lo estético sobre el fondo de la vida cotidiana. "El hombre no llega nunca a darse cuenta de lo antropomórfico que es" (GOETHE apud LUKÁCS, 1982, p. 253).

A arte é estável, constante, atemporal e não está ligada e dependente do critério de verdade científica. Sua função, seu realismo, sua verdade, está posta na sua representação da humanidade histórica. 


\section{A LITERATURA COMO MEDIAÇÃO DA FORMAÇÃO DO SER SOCIAL}

Dessa forma, podemos observar que existe nesse período uma produção artificial de felicidade, um desprendimento do cotidiano, pois no período mágico ainda não se tinha desenvolvido uma ciência e uma arte baseada na realidade objetiva. Esse estágio primitivo afastava o homem do conhecimento, ou seja, de uma elaboração mental e de uma ação prática do conhecido em seu meio. Esta tendência transcendente limitava o homem a um caminho muito mais subjetivo, sendo que todos os instintos humanos implicam numa orientação para fora de si, numa relação com o que está ao seu redor.

Lukács compreende que a partir das necessidades cotidianas do homem, tendo como momento predominante o trabalho, ocorreu o que ele chamou de salto ontológico, pois o homem salta da esfera orgânica para esfera social, o complexo do trabalho, sendo uma atividade consciente e criadora possibilitou efetivar as objetivações humanas e, por meio dele, outros complexos surgiram, como por exemplo, a arte, (FREDERICO, 2014, p.68) "Na visão ontológica de Lukács, a arte é uma atividade que parte da vida cotidiana para, em seguida, a ela retornar, produzindo nesse movimento reiterativo uma elevação na consciência sensível dos homens". A arte é o resultado de determinações sociais realizadas num longo processo de evolução histórica e seu fortalecimento se deu quando grandes crises sociais começaram a ameaçar o domínio das classes que costumavam se apoiar ideologicamente na magia e na religião.

Segundo Lukács (1966, p. 50), “o êxtase e o ascetismo querem remover totalmente o homem de sua vida normal; a realidade transcendente que pretendem impor deve significar uma ruptura absoluta com a vida normal", no sentido do referido autor, o homem está imerso no cotidiano de forma inteira, porém, para que ele perceba certos reflexos precisa se isolar dessa continuidade da vida de forma inteiramente, ou seja, concentrado na arte e na ciência. Terminado essa suspensão temporal formativa ele retorna ao curso normal da vida, esse reflexo da vida de modo provisório não está apartado totalmente dos conteúdos da própria realidade, ao contrário, nesse reflexo alguns conteúdos tendem a se alterar enriquecendo espiritualmente o ser humano com essa experiência. 
Embora no período mágico fossem perceptíveis os elementos do reflexo da realidade e da mímese estes se voltavam para a transcendência. Somente a partir do trabalho buscando responder as carências do cotidiano é que os indivíduos foram se distanciando do reflexo mágico para desenvolver o reflexo científico, que por sua vez, exigiu inicialmente um reflexo consciente possibilitando um nível de abstração e generalização advindas das experiências das ações humanas para assim objetivar determinado fim, isto desencadeou uma transformação social nos seres humanos:

Por isso que essa suspensão pode justificadamente ser considerada como um fato que afeta a forma, uma vez que a formação mimética, tanto objetiva quanto subjetivamente, não realiza, exceto por sua forma específica, a separação temporal da realidade normal, e apenas por sua especificidade a forma produz o efeito desejado de conteúdos reflexivos vitais, os quais, como conteúdos, nascem da vida e a ela retornam. (LUKÁCS, 1966, p. 51).

Neste sentido, podemos identificar que na relação entre a formação mimética e a vida cotidiana, dois aspectos importantes acontecem simultaneamente, por um lado, a prática cotidiana conduz a determinados conteúdos como palavras, gestos dentre outros que causam através da mímese efeitos emocionais e, por outro, que essa interação evocativa produz uma essência formal qualitativa da situação. Nesse processo se percebe a transformação do conteúdo em forma ocorrendo o mesmo inversamente.

O observador ao se o distanciar do fluxo da vida não age neste como uma forma neutra, ao contrário, altera de modo relativo o caráter inicial dos conteúdos ampliando os conhecimentos ao levar em consideração o que foi refletido nesse espaço-temporal. Isto modifica o comportamento humano no retorno ao cotidiano, visto que esse momento de concentração voltado para determinado conteúdos da vida resultam em ações práticas e que as sucessões de acontecimentos ordena os objetivos das partes para uma finalidade. Lukács afirma (1966, p. 53) "a transformação dos dados da vida numa ação, por primitiva que seja é uma fábula." Conforme o autor Húngaro essa categoria da fábula foi imprescindível para o desenvolvimento da literatura, pois a obra literária figura a totalidade para a criação do mundo próprio da obra.

A figuração da totalidade do real é, portanto, essencial para a criação do mundo homogêneo da obra literária. A "totalidade dos objetos", portanto, não é uma 
justaposição pedante de elementos isolados de um suposto "meio", mas nasce a partir de uma necessidade do próprio relato - da representação de destinos humanos, na qual as determinações típicas de um problema social se expressam com base em uma ação. Como imagem da realidade social, do desenvolvimento da sociedade, a ação do romance é dominada pela necessidade (LUKÀCS, 2011, p.211 apud PEREIRA, 2015, p.65).

O que expôs-se até agora, a respeito da vida cotidiana e os reflexos da realidade deságuam no desenvolvimento da arte, por conseguinte na literatura, sendo esta, um tipo de arte. Neste sentido, a fruição de uma obra literária perpassa por esses momentos, nos quais criadores e receptores envolvidos nesta objetivação buscam superar a relação imediata com o objeto, sendo estes extraídos da própria vida, isto distingue um homem inteiro de um homem inteiramente no processo de formação humana, visto que o homem inteiramente estará suspenso temporariamente da continuidade da vida para fruir a obra, seu pensamento estará concentrado evocando emoções, sentimentos que serão traduzidos na prática, no retorno a vida normal e como ser social suas ações expressarão sua verdadeira essência.

Discorreu-se até aqui, sobre o movimento real e existente entre forma e conteúdo. Ambos refletidos a partir da realidade e das contradições da sociedade. Os fenômenos vitais imergem em uma cadeia de relações. O mundo humano refletido está presente na literatura, pois os dramas humanos são históricos.

\section{LITERATURA E REALISMO NA PERSPECTIVA DE LUKÁCS}

Finalmente, pode-se dizer que George Lukács é um mestre da crítica que, no Século $\mathrm{XX}$, tal qual um regente que com a batuta faz malabarismo com os sons da orquestra ao interpretar e executar suas peças, fez ele o mesmo com o universo das palavras ao surpreender e apresentar novas interpretações, novos caminhos e sugerir rumos para o exercício da crítica literária. Assim, como crítico literário, influenciou os estudos da época chegando a ser reconhecido como precursor dos estudos sociológicos da literatura ficcional, mas sabe-se que ele foi muito mais além. Trata-se de um teórico marxista que analisava a obra de arte por meio do seu contexto social e histórico. Era defensor do realismo na literatura e destacava o romance sobre os outros gêneros literários considerando-o a principal forma literária do nosso tempo. 
Lukács tornou-se um singular interprete da estética do século XX. Para ele, “toda autêntica literatura, que reflete de um ou de outro modo a vida da sociedade, deve se basear, em última instância, na dialética entre fenômeno e essência" (LUKÁCS, 2011b, p. 170). Não se pode esquecer que o cotidiano é o centro para onde se convergem as objetivações oriundas da ciência e da arte, consideradas pelo filósofo húngaro como as duas mais puras e elevadas das objetivações que impulsionam o ser social pela busca mais efetiva da realidade.

Para Pereira e Costa (2018, p.9), a teoria lukacsiana e mais especificamente sua defesa pelo realismo deve ser assim entendida:

\begin{abstract}
...como um conjunto de coordenadas estético-filosóficas e um sistema de categorias que possibilitem julgar esteticamente cada obra de arte singular, sem se contrapor ao bic et nunc de cada uma delas. Um método que apreenda a significação social das obras, mas que não as limitem a uma explicação sociológica nem ao julgamento subjetivista do crítico, mas que possa captar a função social e a necessidade a que responde cada objeto de arte.
\end{abstract}

Assim, temos a categoria do realismo ocupando lugar de destaque da crítica marxista, conforme Coutinho (1967, p.106), “[...] para uma crítica marxista e lukacsiana, toda grande arte, todo autêntico reflexo estético da realidade, é realista”. Mas para isso, Lukács evidencia que esse movimento acontece a partir de um processo histórico e agrega a vida do indivíduo à vida da coletividade. Percebe-se portanto, que a obra literária de um autor não pode ser vista como uma cópia ou reprodução da realidade, mas como expressão artística de uma época que se apresente atemporal. Daí porque Lukács buscava a compreensão e o entendimento da sociedade e do ser social a partir das relações históricas, sociais e de classe. Conforme Frederico (2000, p.4) "Na visão ontológica de Lukács, a arte é uma atividade que parte da vida cotidiana para, em seguida, a ela retornar, produzindo nesse movimento reiterativo uma elevação na consciência sensível dos homens".

Vale salientar que, conforme Lukács, a essência do escritor não deve aparecer de maneira abstrata, mas sim como um composto orgânico no quadro dos fenômenos a partir dos quais ela nasce (LUKÁCS, 2010c). De outro modo, conforme ele defende, pautado pelas principais teses do materialismo dialético, o romance realista é a principal expressão literária da burguesia, uma vez que ela privilegia o tipo ao destacar na sua narrativa uma situação típica vivenciada por um personagem típico sob uma perspectiva histórica relevante que 
permite uma ampla compreensão das contradições que configuram a sociedade burguesacapitalista. Lukács apresenta a obra de Honoré de Balzac como aquela que melhor representa essa relação por permitir perceber nos seus livros o indivíduo problemático que constitui o herói típico que tão bem representa esse tipo de romance. Romance que expõe o compromisso entre o homem e o mundo numa sociedade oriunda de um processo histórico dialético e complexo, mas que se aprimora pela práxis do exercício humano.

Toda grande obra de arte, independente do período histórico, tem como condição primordial o objetivo humanista, refletindo o mundo enquanto par dialético essência e aparência. Para tanto, cabe ao artista uma tomada de posição ante à vida, desmascarando a aparência como dissimulação da essência. Nesse sentido, o realismo, enquanto caminho para representação do mundo dos homens é um importante critério para um julgamento fiel da produção artística e esse é o fundamento sobre o qual a estética marxista assenta suas bases. As ponderações lukacsianas ancoram nessa defesa intransigente de uma literatura que toma como fundamento os grandes conflitos morais da existência humana. (DIOGENES, p.106, 2019).

Segundo Diógenes (2019), a concepção de realismo, na esfera da crítica literária, teve como principal referência, conforme já dito, os romances de Honoré de Balzac, pois esse autor apreendeu a dinâmica e as contradições da realidade social de uma forma abundante, compreendendo que o problema histórico é também o problema estético. Como se pode perceber a arte não pode ser vista apenas como uma forma de revelar o mundo exterior, mas como uma práxis social que permite o homem transcender a realidade imediata.

Assim, observa-se que "o verdadeiro artista realista toma partido contra as forças da reificação e, portanto, contra a sociedade desumana, agarrando o núcleo humano, mesmo não tendo nenhum posicionamento político” (DIÓGENES, p.110, 2019).

Dessa forma, segundo Pereira e Costa (2018, p.16).

A arte, comprometida com um reflexo verdadeiro, em suas mais variadas conformações apresenta ao receptor a essência imediatamente na aparência. De algum modo, o produtor de uma obra de arte, mesmo sem ter plena consciência disso, já alcançou a essência da porção de realidade que figura, portanto buscará a melhor maneira de conformar - dar forma - a esse conteúdo da maneira mais adequada a esse fim. Esse é o compromisso do verdadeiro artista, compromisso com a essência da realidade. Mesmo que não haja um vínculo político com alguma causa progressista, mesmo sendo um artista conservador, o realismo triunfa naquelas obras verdadeiras.

Cadernos GPOSSHE On-line, Fortaleza, v. 5, n. 1, 2021 
Logo, o filósofo húngaro defende o Realismo como método e elege o método narrativo como o ideal para um escritor se expressar e alcançar o âmago da obra de arte, em detrimento do método descritivo ao criticá-lo severamente no seu ensaio Narrar ou descrever? Isso não quer dizer que o método descritivo seja abolido do romance porque as coisas podem e devem ser descritas, mas os sentimentos e os percursos humanos devem ser narrados, pois a narrativa realista carrega no seu bojo a essência, a aparência e revela a poesia humana do cotidiano. É a verdade da realidade expressa pelo artista em sua criação. São porções reais de humanidade, que na literatura, se tornam práxis ofertadas ao leitor.

\section{Referências}

COUTINHO, Carlos Nelson. Literatura e Humanismo ensaios a crítica marxista. Rio de Janeiro: Editora Paz e Terra, 1967.

DIÓGENES, Lenha Aparecida da Silva: Gyorge Lukács e Honoré de Balzac: Um Diálogo entre Estética, Literatura e Formação Humana. 2019.221 F. Teses Doutorado em educação) Universidade Federal do Ceará, 2019.

FREDERICO,Celso. A arte no mundo dos homens: o itinerário de Lukács /Celso Frederico.- 1 .ed.- São Paulo: Expressão Popular, 2011.

LUKÁCS, György. Estetica 1: La peculiaridad de lo estetico. Traducido por Manuel Sacristán. v. 1. Barcelona: Ediciones Grijaldo, 1982.

LUKÁCS, Gyorgy. Para uma ontologia do ser social 2/Giorgy Lukács; tradução Nélio Schneider, Ivo Tonet, Ronaldo Vielmi Fortes.- 1. Ed.- São Paulo: Boitempo, 2013.

MARX, Karl. Manuscritos econômicos filosóficos/ Karl Marx; tradução e notas Jesus Ranieri.- [4. reimpr]- São Paulo: Boitempo,2010.il. ( coleção Marx - Engels)

MARX, Karl. A ideologia alemã: crítica da mais recente filosofia alemã em seus representantes Feuerbach, B. Bauer e Stiner, e do socialismo alemão em seus diferentes profetas (1845-1846)/Karl Marx, Friedrich Engels ;supervisão editorial, Leandro Konder; tradução, Rubens Enderle, Nélio Schneider, Luciano Cavini Martorano.- São Paulo: Boitempo, 2007.

NETTO, José Paulo. Economia política: uma introdução crítica /José Paulo Netto e Marcelo Braz. - São Paulo: Cortez,2006. - (Biblioteca básica de serviço social; v.1). 
PEREIRA e COSTA In: Tópicos sobre Realismo Lukcasiano como método históricosistemático. Cadernos GPOSSHE On-line, v.I, n,I. 2018.

SÁNCHEZ Vasquez, Adolfo. Filosofia da práxis- $1^{a}$ ed. Buenos Aires: Consejo latinoamericano de Ciências Sociais- CLACSO; São Paulo: Expressão Popular, Brasil, 2007.

Trabalho oriundo do I Seminário do GPOSSHE - Educação do campo e Pedagogia histórico-crítica em contexto de crise e pandemia 